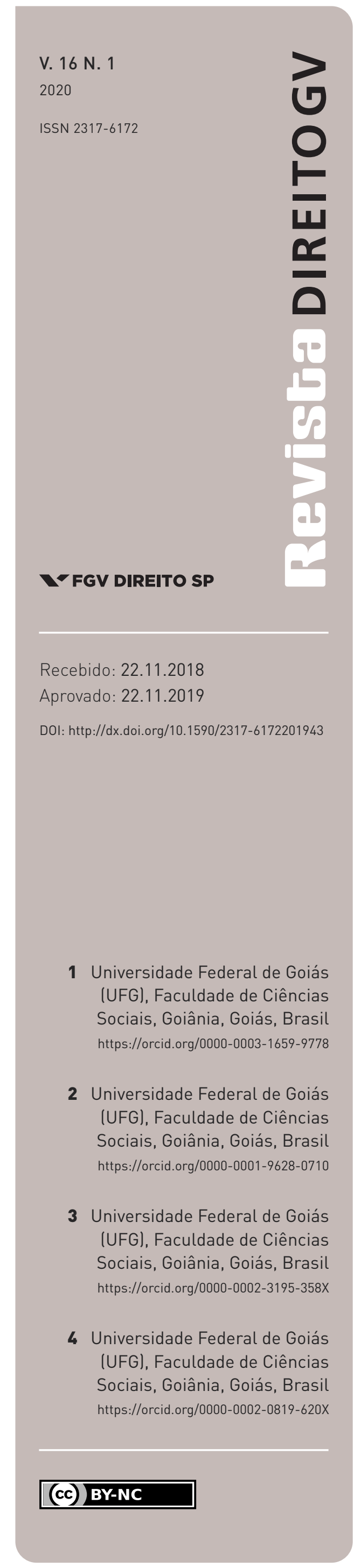

\section{Contraditório e ampla defesa: direitos? O que dizem os processos de apuração de ato infracional entre os anos 2014 e 2017 em Goiânia, Goiás}

ADVERSARIAL SYSTEM AND FULL DEFENSE: RIGHTS? WHAT SAY THE INFRATIONAL ACTION CLEARANCE PROCESS BETWEEN 2014 AND 2017 IN GOIÂNIA, GOIÁS

\author{
Lélia Moreira Borges ${ }^{1}$, Telma Ferreira do Nascimento Durães ${ }^{2}$, \\ Gustavo de Faria Lopes ${ }^{3}$ e Ricardo Barbosa de Lima
}

\section{Resumo}

Este artigo apresenta resultados parciais da pesquisa realizada em Goiânia, no estado de Goiás, entre 2014 e 2017, sobre o direito ao contraditório e à ampla defesa do adolescente em conflito com a lei. A investigação partiu do pressuposto de que os adolescentes submetidos à medida de internação em Goiânia não tiveram garantidos seus direitos ao contraditório e à ampla defesa em seus julgamentos. Para responder a essa hipótese, utilizamos diferentes metodologias, buscando compreender a dinâmica da apuração do ato infracional, desde seu início, com a atuação do sistema de segurança, até a fase final no âmbito da justiça especializada. Confirmamos nosso argumento ao observar duas situações: o recrudescimento de um processo seletivo que orienta o sistema de segurança a exercer maior controle e punição das camadas mais pobres da população; e a atuação do sistema de justiça especial, que conjuga paradoxalmente uma racionalidade própria da justiça penal na condução do processo com um julgamento subjetivo, permeado por valores morais, não rompendo, dessa maneira, com o paradigma da situação irregular.

\section{Palavras-chave}

Adolescente em conflito com a lei; apuração de ato infracional; contraditório e ampla defesa; justiça juvenil; sistema socioeducativo.

\begin{abstract}
This article presents partial results of the research carried out in Goiânia, Goiás, between 2014 and 2017, on the adversarial system and the full defense of the adolescent in conflict with the law. The investigation was based on the assumption that the adolescents submitted to the hospitalization measure in Goiânia were not guaranteed their rights on the adversarial system and the full defense right in their judgments. To answer this hypothesis, we used different methodologies to understand the dynamics of the determination of the infraction, from the beginning, with the performance of the security system, until the final stage in the scope of specialized justice. We confirm our argument by observing two situations: the resurgence of a selective process that guides the security system to exercise greater control and punishment of the poorest sections of the population; and the performance of the special justice system, which paradoxically combines a rationality of criminal justice in the conduct of the process with a subjective judgment permeated by moral values, thus not breaking with the paradigm of the irregular situation.
\end{abstract}

\section{Keywords}

Adolescent in conflict with the law; investigation of an infraction; full defense and adversarial system; juvenile justice; socio-educational system. 


\section{INTRODUÇÃO}

Este artigo visa publicar parte dos resultados alcançados com a pesquisa realizada sobre o sistema de justiça especialmente dirigido aos adolescentes em conflito com a lei em Goiânia, no estado de Goiás. O objetivo principal do trabalho foi averiguar se os adolescentes submetidos à medida socioeducativa de internação tiveram garantidos os direitos ao contraditório e à ampla defesa ${ }^{1}$ em seus julgamentos. Apesar da negação desses direitos fundamentais aos adolescentes submetidos à justiça juvenil brasileira não se revelar como novidade, a intenção dos autores foi de compreender as dinâmicas da apuração do ato infracional em Goiás, lançando um olhar para a práxis do Juizado da Infância e Juventude de Goiânia (JIJ de Goiânia/GO). Nesse sentido, o campo empírico desta investigação consistiu da análise de processos de conhecimento ${ }^{2}$ em fase de arquivamento, em que foi constatada a aplicação de medida de internação; da observação direta de audiências realizadas na Vara de Atos Infracionais ${ }^{3}$ do JIJ de Goiânia/ GO e da realização de entrevistas com agentes da Defensoria Pública.

A Constituição Federal de 1988 (CRFB/88), os Estatuto da Criança e do Adolescente (ECA - Lei n. 9.069/1990), os Códigos Penal, de Processo Penal e de Processo Civil foram referência para este estudo. Ainda, como suporte teórico, foram utilizados autores de diferentes

1 O contraditório e a ampla defesa são princípios norteados pelo princípio maior do devido processo legal previsto no art. 5०, LV da CRFB/88: "Art. 5. Todos são iguais perante a lei, sem distinção de qualquer natureza, garantindo-se aos brasileiros e aos estrangeiros residentes no País a inviolabilidade do direito à vida, à liberdade, à igualdade, à segurança e à propriedade, nos termos seguintes: [...] LV - aos litigantes, em processo judicial ou administrativo, e aos acusados em geral são assegurados o contraditório e ampla defesa, com os meios e recursos a ela inerentes; [...]”. O contraditório e a ampla defesa são princípios do direito segundo os quais o Estado deve assegurar às partes do processo judicial e administrativo os direitos à citação (comunicação eficiente acerca dos fundamentos da instauração do processo do qual é uma das partes) para oportunizar a contra-argumentação face às argumentações e provas apresentadas pela outra parte; à defesa pessoal oral; à apresentação de provas na defesa de seus interesses; e ao acesso a um defensor legalmente habilitado (advogado) e ao duplo grau de jurisdição (direito ao recurso). É nesse aspecto processual que se insere o contraditório, que, de maneira conjunta com o direito à ampla defesa, constitui a participação em igualdade de condições entre acusação e defesa.

2 O processo de conhecimento é a fase judicial da persecução infracional/criminal em que ocorre toda a produção de provas, para além dos documentos apresentados pelo promotor na propositura da ação e pelo defensor na contestação, como a oitiva dos adolescentes, das vítimas e das testemunhas e as alegações finais, a fim de formar o convencimento do juiz quanto aos fatos alegados e para que ele profira a sentença.

3 Ato infracional é, conforme o art. 103 do ECA, a conduta de criança ou adolescente caracterizada como crime ou contravenção, prevista em leis penais aplicáveis para adultos. Neste trabalho, foram analisados apenas casos de prática de ato infracional por adolescentes, uma vez que não se aplicam medidas socioeducativas às crianças, que são penalmente irresponsáveis no caso de cometimento de atos que infrinjam as leis penais, situação em que poderão ser aplicadas as medidas de proteção previstas no art. 101 do ECA. 
matizes e tempos históricos, que oferecem um arcabouço de perspectivas úteis para a reflexão do fenômeno estudado, entre eles, Emilio G. Méndez e Pierre Bourdieu. Também foram utilizados estudos jurídicos e sociológicos já realizados sobre a realidade do sistema socioeducativo brasileiro e em Goiânia, além de dados estatísticos informados pelo Sistema Nacional de Atendimento Socioeducativo (Sinase). Partimos do pressuposto de que os adolescentes submetidos à medida de internação em Goiânia não tiveram garantidos os direitos ao contraditório e à ampla defesa em seus julgamentos.

Este artigo está estruturado em três partes. Na primeira parte, apresentamos a metodologia adotada para a realização da pesquisa e descrevemos o campo; em seguida, à luz da teoria do campo jurídico de Pierre Bourdieu (1989), descrevemos a maneira como o sistema de segurança e de justiça estão estruturados e o modo como se articulam no âmbito do que denominamos de subcampo do direito da criança e do adolescente; na última parte, detalhamos a análise dos dados produzidos empiricamente no campo da pesquisa, sob o ponto de vista da gestão de provas aplicáveis às distintas fases que compõem a persecução infracional.

\section{I.TÉCNICAS E ABORDAGENS NO CAMPO EMPÍRICO DA PESQUISA}

Foram consultados 178 processos que tramitaram no período de 2014 a 2016. Foram assistidas, no ano de 2017, 15 audiências, sendo elas 7 de apresentação e 8 de continuação. Dos 178 processos, analisaram-se 59 de conhecimento para coletas de dados, em razão da existência da medida de internação provisória e/ou definitiva aplicada na audiência de apresentação ou na sentença. Esse número correspondeu a 33,1\% do total do universo consultado. O restante foi descartado, porque se tratava de processos de conhecimento de aplicação de medidas socioeducativas em meio aberto ou de autos processuais de execução de medidas aplicadas aos adolescentes, contendo apenas algumas peças processuais extraídas do respectivo processo de conhecimento. É por meio desse tipo de processo que se apura a suposta prática de ato infracional. Inicia-se com representação pelo Ministério Público (MP), a partir do protocolo da petição de acusação, podendo culminar na aplicação de medidas protetivas e/ou socioeducativas, ${ }^{4}$

4 Importante apresentar a existência de duas modalidades distintas de medidas aplicáveis ao subcampo do direito da criança e do adolescente. A primeira delas é a medida de proteção, que deverá ser aplicada sempre que verificada ameaça ou violação dos direitos da criança e do adolescente, por ação ou omissão da sociedade ou do Estado, ou por abuso dos pais ou do responsável e em razão da própria conduta da criança ou do adolescente. São oito as medidas definidas no ECA, em seu art. 101: I) encaminhamento aos pais ou responsável, mediante termo de responsabilidade; II) orientação, apoio e acompanhamento temporários; III) matrícula e frequência obrigatórias em estabelecimento oficial de ensino fundamental; IV) inclusão em programa comunitário ou oficial, de auxílio à família, à criança e ao adolescente; V) requisição de tratamento médico, psicológico ou psiquiátrico, em regime hospitalar ou ambulatorial; VI) inclusão em programa oficial ou comunitário 
em meio aberto ou fechado; absolvição ou remissão ${ }^{5}$ (com ou sem aplicação de medida em meio aberto); ou extinção do processo sem decisão de mérito, por exemplo, quando o acusado morre ou atinge a maioridade penal (18 anos).

Desse modo, os documentos produzidos ao longo da persecução infracional, ${ }^{6}$ que vai desde o inquérito policial até a sentença definitiva, permitiram obter informações relevantes, a partir das quais foram definidas as variáveis e as categorias de análise ${ }^{7}$ úteis à compreensão de nosso objeto de pesquisa, como o perfil socioeconômico dos adolescentes; a apreensão em flagrante; o ato infracional imputado pelo MP; a aplicação da medida de internação provisória e sua duração; a presença ou não de advogado particular ou defensor público na audiência informal com o MP; o tempo de duração do processo; a produção de provas; a confissão do adolescente e a proporcionalidade da medida adotada em relação ao ato infracional atribuído.

Outra técnica de investigação utilizada foi presenciar, em 2017, as audiências de apresentação e de continuação. ${ }^{8}$ Nelas, observou-se como os atores do processo posicionam-se tanto geograficamente no espaço físico da sala quanto nas manifestações orais que, em razão das regras do procedimento, são gravadas em mídia de áudio e vídeo. Nessas ocasiões, utilizou-se o diário de campo, pois não foi permitido aos pesquisadores gravar as falas. Foi possível assistir

de auxílio, orientação e tratamento a alcoólatras e toxicômanos; VII) abrigo em entidade; VIII) colocação em família substituta. As outras modalidades são as medidas socioeducativas, as quais são aplicáveis apenas ao adolescente entre 12 e 17 anos, que, depois do devido processo, foi considerado responsável pelo cometimento de um ato infracional. Essas medidas são as dispostas no artigo 112, incisos I a VI: advertência; obrigação de reparar o dano; prestação de serviços à comunidade; liberdade assistida; inserção em regime de semiliberdade; internação em estabelecimento educacional. Além dessas medidas, poderão ser aplicadas ao adolescente (ECA, art.112, inciso VII) as medidas protetivas previstas no artigo 101, incisos I a VI.

5 A remissão consiste no perdão e é uma forma de excluir, extinguir ou suspender o processo de apuração do ato infracional. Encontra-se regulada nos artigos 126 a 128 do ECA. Têm-se duas espécies de remissão: a ministerial e a judicial.

6 Trata-se da atividade estatal destinada à aplicação de medida socioeducativa por meio do procedimento para apuração de ato infracional. Semelhante à persecução criminal, é composta por duas fases: a investigação, de competência da polícia judiciária, inaugurada, na maioria dos casos, por meio da apreensão em flagrante delito pela Polícia Militar; e a fase judicial, iniciada por meio da representação infracional de responsabilidade do MP.

7 No desenvolvimento da pesquisa, foram analisadas todas essas variáveis em 59 processos, totalizando 90 casos de adolescentes processados e julgados por ato ilícito e que, em algum momento (no início e/ou no final do processo), foram internados. Para este artigo, selecionamos apenas informações obtidas a partir dessas categorias analisadas, que nos permitiram compreender como o exercício do contraditório e da ampla defesa é conduzido nas fases da persecução infracional - do inquérito à decisão judicial de primeiro grau e do duplo grau jurisdicional da justiça juvenil, quando existente.

8 Foram ao todo 15 audiências (7 de apresentação e 8 de continuação). 
a dois tipos de audiências, a de apresentação e a de continuação; na primeira, o juiz interroga o acusado, podendo ou não aplicar a internação provisória, definindo se o adolescente responderá ao processo em liberdade ou não. Na segunda, em audiência de continuação, o juiz deve instruir o processo, ou seja, oportunizar a produção de provas pelas partes e, ao final, proferir a sentença, definindo a aplicação ou não da internação definitiva.

Além da coleta de informações nos processos no diário de campo, foram realizadas duas entrevistas semiestruturadas com dois defensores públicos atuantes naquele juizado, com a finalidade de melhor compreender a estrutura da instituição que representam e, também, como são elaboradas as estratégias de defesa de adolescentes acusados de ato infracional. As entrevistas ocorreram em salas da Defensoria Pública, o que contribuiu, junto com as respostas dos profissionais, para perceber as limitações existentes tanto da estrutura material quanto do reduzido número de profissionais disponíveis.

\section{O SUBCAMPO DO DIREITO DA CRIANÇA E DO ADOLESCENTE: ENTRE A TEORIA E A PRÁTICA} Para compreender os mecanismos de atribuição de responsabilidade aos menores de 18 anos no Brasil, é necessário, em primeiro lugar, conhecer como se organizam e como atuam os órgãos de segurança e de justiça do sistema socioeducativo, para logo após apresentar uma análise da atuação desses órgãos e sua correlação com o exercício do direito ao contraditório e à ampla defesa dos adolescentes em conflito com a lei em Goiânia, elementos que compõem o subcampo do direito da criança e do adolescente, quais sejam: Polícias Militar e Civil, MP, Defensoria Pública, JIJ e técnicos do sistema socioeducativo.

As Polícias Civil e Militar, o MP, o JIJ e a Defensoria Pública são os principais órgãos estatais competentes a atuar no âmbito da persecução infracional, segundo as regras fixadas por um conjunto de normas de direito processual penal previstas no ECA, no Código de Processo Penal e Civil e na lei do Sinase que, a partir da lógica constitucional vigente, devem ser aplicadas e interpretadas conforme os princípios do contraditório e da ampla defesa do investigado/acusado.

A definição de campo jurídico de Bourdieu (1989, p. 212) serviu como ponto de partida para entender como se organizam o sistema socioeducativo e suas dinâmicas:

O campo jurídico é o lugar de concorrência pelo monopólio do direito de dizer o direito, quer dizer, a boa distribuição (nomos) ou a boa ordem, na qual se defrontam agentes investidos de competência ao mesmo tempo social e técnica que consiste essencialmente na capacidade reconhecida de interpretar (de maneira mais ou menos livre ou autorizada) um corpus de textos que consagram a visão legítima, justa, do mundo social.

A partir desse conceito é que foi estabelecida a metodologia de pesquisa de campo, não só para traçar a estrutura desse subcampo do direito da criança e do adolescente no Brasil, mas, 
sobretudo, para perceber as correlações de forças internas entre os agentes do campo e externas a ele, e com isso entender como este tem sido o lugar de concorrência pelo monopólio do direito de dizer o direito, nos casos concretos levados à justiça especializada para julgamento de adolescentes em conflito com a lei.

Dessa maneira, veremos que a concorrência entre os intérpretes é limitada, na medida em que se apresenta como resultado de uma interpretação regulada de textos unanimemente reconhecidos. Além disso, é preciso compreender que não só as normas e as interpretações conferem a autoridade de suas decisões, mas também a organização da Justiça de maneira hierárquica, no que diz respeito às instâncias e aos espaços de poder (BOURDIEU, 1989).

A persecução de atos infracionais praticados por adolescentes é composta por dois sistemas processuais distintos: o inquisitivo e o acusatório, de maneira análoga à persecução penal voltada a apurar crimes praticados por adultos. ${ }^{9} \mathrm{O}$ sistema inquisitivo é aplicado na fase de investigação, ${ }^{10}$ realizada pelos órgãos de segurança, marcada pelo sigilo de seus atos, sem a participação ativa do acusado e sem a observância do exercício do contraditório e da ampla defesa. Essa fase, que não é obrigatória, inicia-se, por regra, com a apreensão do adolescente pelos agentes da Polícia Militar, que por sua vez o direcionam à Polícia Civil, ${ }^{11}$ dando início ao inquérito policial e posterior encaminhamento do caso ao $\mathrm{MP},{ }^{12}$ que decidirá pela judicialização ou não do caso, após a oitiva informal. ${ }^{13}$

Uma vez iniciada a fase acusatória da persecução, por meio da Representação do Ato Infracional dirigida ao Poder Judiciário, distintamente da fase inquisitiva, há o dever, por parte dos agentes do Estado, de observar de maneira rigorosa os princípios do contraditório e da ampla defesa, a fim de prevenir erros e excessos tanto na condução do julgamento quanto na decisão proferida, ao final, pela autoridade judiciária, que poderá culminar com a aplicação de medidas socioeducativas. ${ }^{14}$

9 Como estabelecido nos arts. 152 a 154; arts. 191 a 197, todos do ECA.

10 Conforme previsto no art. 20 do Código de Processo Penal, que dispõe: “A autoridade assegurará no inquérito o sigilo necessário à elucidação do fato ou exigido pelo interesse da sociedade”.

$11 \mathrm{O}$ art. 172 do ECA prevê que o adolescente apreendido em flagrante de ato infracional será, desde logo, encaminhado à autoridade policial competente.

12 Conforme o art. 175 do ECA, em caso de não liberação, o adolescente será encaminhado, desde logo, ao representante do MP com cópia do auto de apreensão ou boletim de ocorrência.

13 Procedimento no qual o adolescente é inquirido pelo membro do MP, para que este forme sua convicção sobre o cometimento do ato infracional.

14 O art. 98 do ECA prevê aplicação cumulativa de medidas socioeducativas e de proteção aos adolescentes em conflito com a lei. Contudo, o que pode ser observado e descrito adiante é o predomínio, no JIJ de Goiânia, da aplicação de medidas socioeducativas, deixando de aplicar as medidas protetivas previstas no 
Dessa feita, as normativas que dispõem sobre as relações jurídico-processuais, e que preveem direitos e impõem deveres e obrigações aos sujeitos do processo, adotam, pelo menos teoricamente, como princípios balizadores, o exercício do contraditório e da ampla defesa do acusado, próprio de um Estado democrático de direito, que pressupõe sua observância como instrumento jurídico e político necessário para legitimar as decisões judiciais relativas aos adolescentes no sistema socioeducativo.

Tem-se que, no julgamento do ato infracional, estão em jogo dois interesses distintos. Um refere-se à efetividade da tutela jurisdicional, por suposta ofensa a direito protegido pela lei penal, e o outro, à efetividade do direito de defesa dos acusados. Segundo lição da teoria geral do processo: "Cada um desses interesses incide num plano distinto, sem que se produza qualquer espécie de antinomia” (MARINONI, 2008, p. 88). O primeiro, jus puniendi, exige seleção de um meio idôneo para proteção do direito reivindicado; e o segundo, jus libertatis, exige o uso do meio idôneo menos lesivo ao cidadão afetado pela decisão. Sendo assim, em termos legais, o "Estado se submete diretamente ao direito fundamental à tutela jurisdicional - em um teste de necessidade ou lesividade mínima, vez que essa eficácia pode se refletir ou repercutir sobre a parte, e por isso, a sua legitimidade está condicionada à análise do direito de defesa" (MARINONI, 2008, p. 89).

Uma das garantias processuais na esfera penal, considerada uma conquista histórica, é a jurisdicionalidade, que corresponde ao monopólio do Estado na aplicação da pena, evitando-se, com isso, a vingança privada. O Estado intervém na vida das pessoas, absolvendo-as ou aplicando-lhes sanções penais por meio do processo, que deve ser, ao mesmo tempo, instrumento para aplicação de penalidade e protetor dos direitos e garantias. E, se de um lado, as regras de processo e procedimento são instrumentos do exercício da jurisdição, esta, em si, entendida como o ato de dizer o direito do caso concreto, é realizada por meio de juízo interpretativo da norma de direito material, que, historicamente, no âmbito do sistema juvenil brasileiro, tem sido orientada por diferentes paradigmas nesse subcampo.

O paradigma da situação irregular ${ }^{15}$ estabelecida pelo Código de Menores ${ }^{16}$ e o paradigma

art. 101, mesmo quando constatados os parâmetros indicados no art. 100 do ECA: a) necessidade pedagógica e b) preferência por medidas que fortaleçam os vínculos familiares e comunitários.

15 A doutrina da situação irregular é o modelo sociojurídico da legislação infantojuvenil que orienta a ação estatal dirigida a crianças e adolescentes em condições definidas como irregulares. Possui como principal foco a atuação assistencial, a proteção e a vigilância aos menores de dezoito anos. Essa doutrina foi encampada expressamente pelo Código de Menores (BRASIL, 1927; BRASIL, 1979). O termo "situação irregular" era utilizado para definir situações que fugiam ao padrão normal da sociedade. Assim, por exemplo, consideravam-se em situação irregular os menores abandonados, vítimas de maus-tratos, miseráveis, além dos infratores. O pressuposto de aplicação da lei seria o não enquadramento do menor na sociedade regular.

Lei n. 6.697/1979. 
da proteção integral ${ }^{17}$ apresentaram-se como as bases jurídicas e filosóficas do subcampo do direito da criança e do adolescente. O fundamento da proteção integral intencionou promover uma ruptura com o antigo paradigma; todavia, pelo que indicam os resultados deste trabalho, essa ruptura ainda não ocorreu integralmente, uma vez que a concepção do novo paradigma ainda não se encontra devidamente sedimentada, sem os dogmatismos jurídicos que informavam o julgamento de adolescente antes da CRFB/88 e do ECA. O paradigma da proteção integral define a observância obrigatória pelo Estado dos princípios jurídicos processuais, antes ausentes na legislação menorista, os quais reconhecem que tanto a criança como o adolescente são sujeitos, e não objetos de direitos.

O paradigma da proteção integral, em que pese não se encontrar efetivamente consolidado, é a categoria jurídica que inova o sistema de garantias processuais do direito ao contraditório e à ampla defesa dos adolescentes em conflito com a lei. Os arts. 110 e 111 do ECA, em sintonia com a CRFB/88, preveem que nenhum adolescente será privado de sua liberdade sem o devido processo legal e que deverá ser-lhe assegurado, entre outros, o pleno e formal conhecimento da atribuição do ato infracional, mediante citação ou meio equivalente. A igualdade na relação processual consiste, portanto, na oportunidade de confrontação de vítimas e testemunhas, incluindo a defesa técnica por advogado; a assistência judiciária gratuita e integral aos necessitados; o direito de ser ouvido pessoalmente pela autoridade competente; e o direito de solicitar a presença de seus pais ou responsável em qualquer fase do procedimento, entre outros direitos fundados no princípio do contraditório e da ampla defesa, que forma a base do devido processo legal.

O termo proteção integral popularizou-se e vem sendo objeto de interpretações equivocadas por parte da sociedade, estimulada especialmente pela grande mídia que, de maneira ideológica, ${ }^{18}$ apresenta as garantias estabelecidas na lei como privilégios, desconsiderando o fato de que, com os direitos, vieram também os deveres e as responsabilidades correspondentes,

17 O paradigma da proteção integral é o modelo sociojurídico introduzido no ordenamento jurídico pelo art. 227 da CRFB/88, que declarou ser dever da família, da sociedade e do Estado assegurar à criança e ao adolescente, com absoluta prioridade, o direito à vida, à saúde, à alimentação, à educação, ao lazer, à profissionalização, à cultura, à dignidade, ao respeito, à liberdade e à convivência familiar e comunitária, além de colocá-los a salvo de toda forma de negligência, discriminação, exploração, violência, crueldade e opressão. Adotada pelo ECA, assenta-se na concepção de que a criança e o adolescente são sujeitos de direito, deixando de ser tratados como objetos passivos para se tornarem titulares de direitos; destinatários de absoluta prioridade, respeitando-lhes a condição peculiar de pessoa em desenvolvimento. Segundo esse entendimento, o ECA não deve dirigir-se apenas a um tipo de jovem, mas sim a toda a juventude e a toda a infância.

18 Termo utilizado no sentido apresentado por Karl Marx. De acordo com Löwy (1985): “O conceito de ideologia aparece em Marx como equivalente de ilusão, falsa consciência, concepção idealista, na qual a realidade

é invertida e as ideias aparecem como motor da vida real". No marxismo posterior a Marx, sobretudo na obra 
inclusive a de responder pelos atos ilícitos por meio do cumprimento de medidas socioeducativas. ${ }^{19}$ A percepção de que o sistema socioeducativo não cumpre o papel de responsabilizar o adolescente que comete ato infracional afeta a estabilidade de garantias constitucionais, em um momento histórico de crescente clamor pela redução da maioridade penal.

As bases constitucionais do Estado democrático são "liberdade, igualdade e participação, em clima de legalidade e responsabilidade” (COSTA, 2005, p. 97). O contrário disso seria um processo penal/infracional autoritário, típico de um Estado antidemocrático. A presente pesquisa aponta que a ação inquisitorial tem peso preponderante na persecução infracional, o que revela, como veremos à frente, um sistema de segurança e de justiça juvenil de baixíssimo nível democrático, se entendermos que "violações às garantias constitucionais da criança e do adolescente servem de termômetro para aferir o grau de democracia de um país" (MÉNDEZ e BELOFF, 2001, p. 21-24).

\section{I Perfil socioeconômico dos(as) Adolescentes apreendidos(AS) E A Seletividade do SISTEMA SOCIOEDUCATIVO}

Para compreender o subcampo do direito da criança e do adolescente, não basta conhecer sua estrutura e a dinâmica de atuação de seus agentes; é necessário, também, conhecer aqueles sobre os quais incidem tais ações: os(as) adolescentes submetidos(as) ao sistema socioeducativo. Uma análise do perfil de adolescentes apreendidos revela a existência de critérios socioeconômicos que definem um grupo social a ser institucionalizado.

Os dados informam que a maioria é de meninos de 16 e 17 anos, negros, fora da escola, com ensino fundamental incompleto, desempregados e moradores de bairros periféricos de Goiânia; assistidos, na maioria dos casos, pela Defensoria Pública, como veremos logo a seguir de maneira mais detalhada. Esses resultados são compatíveis com os dados oficiais registrados no Plano Estadual do Socioeducativo de Goiás, publicado em 2015, referentes ao ano de 2013, no qual consta que 94\% dos jovens são homens, 86\% têm entre 15 e 17 anos e $86 \%$ são não brancos.

Essas informações apontam a existência da seletividade relacionada às questões sociais, marcada pela desigualdade de oportunidades oferecidas aos adolescentes negros e pardos das classes populares. Estes são selecionados para compor um tipo social "propenso a cometer crime”, expostos, quando inseridos no sistema socioeducativo, em particular no sistema fechado, a situações aviltantes e degradantes.

de Lênin, ganha outro sentido, bastante diferente: ideologia é qualquer concepção da realidade social ou política, vinculada aos interesses de certas classes sociais particulares (LÖWY, 1985, p. 12).

Com essas modificações, o conceito de inimputabilidade sofreu alterações, como já tratado. 
De acordo com o relatório, os constantes entupimentos nos encanamentos dos banheiros espalham um odor semelhante a esgoto, que reforça o aspecto insalubre do lugar. O ambiente "sombrio", por sua vez, pode estar ligado a outros fatores que não a iluminação. Essa expressão ganha ainda mais sentido se considerarmos que um dos questionamentos dos adolescentes é acerca da agressão sofrida por policiais militares. Cogito que a violência ali presente pode ter feito o ambiente "sombrio" até para quem não é vítima dela. (SANTIBANEZ, 2016, p. 43)

O tratamento conferido aos adolescentes pelo sistema de segurança e de justiça é pautado pelas representações construídas acerca de suas trajetórias de vida e do grupo social a que pertencem. O modo como é determinado o não acesso desses adolescentes a bens materiais e imateriais da sociedade define o trato dado a eles no trâmite da persecução infracional. Exemplos disso são os pareceres emitidos pelos assistentes sociais que atendem os adolescentes apreendidos na delegacia, que privilegiam aspectos relacionados ao ato infracional e às passagens anteriores por delegacias. As informações de conteúdo pessoal são, na maioria das vezes, depreciativas. Essa situação foi verificada também nas petições do MP e dos juízes, assim como nas abordagens em audiência, na fase judicial.

De outro lado, a leitura quantitativa dos dados produzidos a partir dos 90 casos analisados nos permite verificar o modo como as instituições se posicionam na persecução infracional e como usualmente atuam seus agentes. A começar pelo perfil dos adolescentes, 85,6\% são do sexo masculino e 14,4\%, do feminino; 51\% têm 17 anos, 33,3\% têm 16 anos, 13,3\% têm 15 anos. Segundo a cor informada nos inquéritos policiais, 63\% são pardos, ${ }^{20} 13,3 \%$ são negros, 15,6\% são brancos e 7\% são das demais cores; quanto à escolaridade, 76,7\% têm o fundamental incompleto, 3,3\% têm fundamental completo e 18\%, o ensino médio incompleto (não foi encontrado nenhum caso de adolescente cursando o ensino superior e, ainda, 76,7\% estavam fora da escola e 91,1\%, desempregados.

A relação entre os índices de homicídios praticados contra adolescentes no Brasil e o perfil dessas vítimas é um dado importante para demonstrar a mencionada seletividade do sistema. De acordo com o Mapa da Violência de 2015, foi registrado, em 2013, um total de 8.153 mortes de adolescentes de 16 e 17 anos de idade, "73,2\% por causas externas e 26,8\% por

20 Consideraram-se cinco categorias para a pessoa se classificar quanto à característica cor ou raça: branca, preta, amarela (compreendendo-se nessa categoria a pessoa que se declarou de raça amarela), parda (incluindo-se nessa categoria a pessoa que se declarou mulata, cabocla, cafuza, mameluca ou mestiça de preto com pessoa de outra cor ou raça) e indígena (considerando-se nessa categoria a pessoa que se declarou indígena ou índia). Definição encontrada no site do Instituto Brasileiro de Geografia e Estatística (IBGE). Disponível em: http://www.ibge.gov.br/home/estatistica/populacao/trabalhoerendimento/pnad99/metodologia99. shtm. Acesso em: 20 jul. 2017. 
causas naturais. Entre as mortes por causas externas, apresentam especial incidência os homicídios, que ceifaram a vida de 3.749 jovens. Isso representa $46 \%$ do total de mortes acontecidas nesta faixa, quase a metade do total de mortes" (WAISELFISZ, 2015, p. 25). Ainda nessa publicação, os números mostram que a região Centro-Oeste assume especial destaque pelas elevadas taxas de homicídio que ostenta: 65,3 por 100 mil adolescentes.

No quesito raça/cor, em que só duas categorias foram usadas, branco e negro, ${ }^{21}$ esta última resultante do somatório de pretos e pardos, verificou-se, pela análise de tabelas e gráficos, que, em 2013, na faixa etária de 0 a 17 anos de idade, morreram, vítimas de homicídio, 1.127 crianças e adolescentes brancos e 4.064 negros; 703 dos brancos (62,4\%) e 2.737 dos negros $(67,3 \%)$ tinham 16 e 17 anos de idade. "Proporcionalmente, morreram quase três vezes mais negros que brancos" (WAISELFISZ, 2015, p. 28).

A seletividade, portanto, é um aspecto importante para a compreensão da ação do sistema de segurança e de justiça que está voltado para dar respostas punitivas aos adolescentes de classe social popular, marginalizados ainda na fase inquisitorial, os quais compõem a maioria das vítimas de mortes violentas, levando-nos a entender que:

A despeito do discurso de conquistas de direitos de um lado e de outro a marginalização crescente em razão do desemprego crônico, de crise econômica e política, a análise do discurso de educação/reeducação, a despeito da magnanimidade de muitos dos nossos reformadores, longe de constituir apenas um gesto de humanidade, na verdade, serviu de obstáculo à formação de uma consciência mais ampla de cidadania no país. (RIZZINI, 1997, p. 35)

Apesar das transformações econômicas e políticas pelas quais o Brasil passou, sua história revela que o pressuposto da desigualdade que fundou o país ainda persiste, e a discriminação racial continua impondo obstáculos aos negros, que, apesar de libertos da escravidão, encontram-se marginalizados.

[...] a manutenção de critérios racialmente discriminatórios que, obstaculizando sua ascensão à simples condição de gente comum, igual a todos os demais, tornou mais difícil para ele obter educação e incorporar-se na forma de trabalho dos setores modernizados. As taxas de analfabetismo, de criminalidade e de mortalidade dos negros são, por isso, as mais elevadas, refletindo o fracasso da sociedade brasileira. (RIBEIRO, 1995, p. 220)

21 O SIM, do Ministério da Saúde, que centraliza as informações das declarações de óbito, acompanha a classificação proposta pelo IBGE, com as cinco categorias mencionadas. 
O direito penal pode ser considerado uma conquista histórica diante das arbitrariedades do Estado absolutista, uma vez que se apresentou como instrumento de defesa da sociedade civil e do indivíduo face à ação do próprio Estado. Contudo, apesar de anunciar a garantia de direitos do cidadão, por outro lado estabeleceu a proteção da propriedade privada pelo controle penal para quem infringir as regras sociais. Nesse passo, o delito contra o patrimônio constituiu a base político-legislativa para a criação de normas penais. Para tanto, utilizam os pressupostos da imputabilidade, da culpa e da punição. Essa mesma lógica preside os procedimentos de apuração de ato infracional no subcampo do direito da criança e do adolescente, dada a ancoragem do ECA ao código penal para adultos.

Os instrumentos formais para limitar a ação do controle penal do Estado foram um avanço, pois asseguram direitos ao cidadão, uma vez que o Estado só poderá condenar se a conduta estiver prevista em lei. No entanto, isso não resolve as contradições da origem do direito penal. O que corresponde, na prática, como meio "justificado" para preservação do patrimônio particular. "A ideologia transforma fins particulares em fins universais, encobre as tarefas que o direito penal desempenha para a classe dominante, travestindo-as de interesse social geral, e empreende a mais essencial inversão, ao colocar na linha de fins da lei” (BATISTA, 2002 , p. 112). O roubo, crime contra o patrimônio, foi o tipo de ato infracional mais verificado nesta pesquisa, e a Tabela 1 indica a similitude dessa situação com dados apresentados pelo Conselho Nacional de Justiça (CNJ), ${ }^{22}$ o qual demonstra que o roubo qualificado encabeça a segunda posição no ranking de atos infracionais mais cometidos por adolescentes entre 12 e 17 anos de idade, somando o total de 51,4 mil ocorrências.

TABela 1 - Processo de APURAÇÃo de ATo infracional POR TIPO PenAl, APONTADO Pelo Ministério Público

\begin{tabular}{lllll} 
& FREQUÊNCIA & PERCENTUAL & $\begin{array}{l}\text { PERCENTUAL } \\
\text { VÁLIDO }\end{array}$ & $\begin{array}{l}\text { PERCENTUAL } \\
\text { CUMULATIVO }\end{array}$ \\
\hline TENTATIVA DE ROUBO & 15 & 16,7 & 16,7 & 16,7 \\
\hline FURTO & 4 & 4,4 & 4,4 & 21,1 \\
\hline
\end{tabular}

(continua)

22 Disponível em: https://exame.abril.com.br/brasil/os-crimes-mais-cometidos-por-adolescentes-no-brasil/. Acesso em: 19 nov. 2018. 


\begin{tabular}{lcccc} 
& FREQUÊNCIA & PERCENTUAL & $\begin{array}{l}\text { PERCENTUAL } \\
\text { VÁLIDO }\end{array}$ & $\begin{array}{l}\text { PERCENTUAL } \\
\text { CUMULATIVO }\end{array}$ \\
\hline TENTATIVA DE FURTO & 1 & 1,1 & 1,1 & 22,2 \\
\hline TRÁFICO & 9 & 10,0 & 10,0 & 32,2 \\
\hline HOMICÍDIO & 2 & 2,2 & 2,2 & 34,4 \\
\hline TENTATIVA DE HOMICÍDIO & 4 & 4,4 & 4,4 & 38,9 \\
\hline ROUBO & 50 & 55,6 & 55,6 & 94,4 \\
\hline PORTE ILEGAL DE ARMAS & 1 & 1,1 & 1,1 & 95,6 \\
\hline LESÃO CORPORAL & 4 & 4,4 & 4,4 & 100,0 \\
\hline TOTAL & 90 & 100,0 & 100,0 &
\end{tabular}

Fonte: Elaboração própria, a partir de dados produzidos dos processos de conhecimento, consultados no JIJ Goiânia/GO.

O código penal, portanto, em grande medida, é direcionado às pessoas de baixo poder aquisitivo e orientado para punir delitos praticados contra o patrimônio. É evidente que pessoas de nível econômico elevado também praticam crimes, contudo, possuem bons advogados e contam com a benevolência da sociedade e do Poder Judiciário. A legislação penal, ainda que apresente um discurso pautado pela igualdade entre a punição dos crimes de "colarinho branco" e a dos crimes contra o patrimônio, em uma leitura mais apurada, deixa transparecer que o tratamento dos crimes em questão é desigual. O art. 34 da Lei n. 9.249/1995 exemplifica essa situação, quando diz: "Extingue-se a punibilidade dos crimes definidos na Lei n. 8.137, de 27 de dezembro de 1990, e na Lei n. 4.729, de 14 de julho de 1965, quando o agente promover o pagamento do tributo ou contribuição social, inclusive acessórios, antes do recebimento da denúncia" (BRASIL, 1995).

O controle penal dos adolescentes em conflito com a lei responde aos anseios da sociedade que reclama por mais "rigor" da legislação penal para resolver o problema da "delinquência juvenil”. Contudo, os dados sobre práticas criminais revelam a falácia dos argumentos difundidos pela grande mídia de que o problema da violência é, em parte considerável, causado pelo crescente número de "menores infratores".

Conforme a Tabela 2, a comparação entre a quantidade de delitos praticados por adultos e aquela por adolescentes demonstra que os atos infracionais praticados por jovens de 12 a 18 
anos ocorrem em uma frequência bem menor que os delitos praticados por adultos. Os adolescentes são responsáveis por 17\% do total de latrocínios, por 1\% do total de furtos, por 2,5\% do total de roubos e por 3\% dos homicídios registrados em Goiânia no ano de 2013, ${ }^{\mathbf{2 3}}$ de modo que não procede a ideia de que o adolescente é o principal responsável pela incidência de crimes na cidade. E ainda, se comparado com o número absoluto de adolescentes que praticam atos infracionais em Goiânia,

[...] apenas $0,5 \%$ da população de adolescentes está em conflito com a lei. Tal constatação vai de encontro ao discurso corrente entre os agentes do sistema, que alardeiam um suposto número elevado de adolescentes infratores; enquanto, na verdade, 99,5\% dos/as adolescentes não cometeram atos infracionais. (SANTIBANEZ, 2016, p. 36)

tabela 2 - Autoria de CRime POR GRUPO ETÁrio EM GoiÂniA NO ANO DE 2013

ADULTOS

25.964

19.305

589

28

5
ADOLESCENTES

243

490

20

LATROCÍNIO

Fonte: SANTIBANEZ (2016, p. 35), a partir de dados da Secretaria de Segurança Pública do Estado de Goiás e da Delegacia de Apuração de Atos Infracionais.

A proteção dos bens como fundamento à punição, à neutralização ou ao afastamento do "delinquente" como justificativa para a aplicação de medidas socioeducativas é estratégia para alcançar a confiança coletiva de que o Estado é capaz de restabelecer a paz por meio do sistema jurídico penal. Com isso, os adolescentes são punidos pelo que poderão vir a fazer, como modo de enquadramento dos adolescentes pobres e negros na sociedade, desconsiderando

\footnotetext{
$\cdots$

23 Santibanez (2016).
} 
sua condição de pessoa em desenvolvimento. E, sob esse aspecto, é notória a influência de forças externas ao subcampo do direito da criança e do adolescente no direcionamento das atuações dos agentes desse subcampo (BOURDIEU, 1989).

A inimputabilidade, por sua vez, prevista no ECA, distancia-se muito pouco da imputabilidade penal dos adultos, uma vez que prestigia a aplicação de medidas socioeducativas, verdadeiras sanções, em detrimento das medidas protetivas que se fazem necessárias ao adolescente na garantia de sua liberdade, para seu desenvolvimento físico e mental. O que se passa é que o ato infracional constitui o passaporte para a entrada, na maioria das vezes conduzida pelas mãos da polícia, do adolescente no sistema de segurança e de justiça juvenil, que prestigia a punição em lugar do paradigma da proteção integral introduzida no estatuto.

Além disso, a ação seletiva do sistema de segurança e de justiça juvenil corrobora para uma identificação estereotipada do jovem acusado de prática de ato infracional, ainda chamado de "menor delinquente". Esse estereótipo é reforçado pelos meios de comunicação e pela ação dos agentes de segurança, pelo conformismo e pela aceitação da sociedade de que essas circunstâncias são normais.

Goffman (1988), em sua obra Estigma - Notas sobre a manipulação da identidade deteriorada, oferece um argumento teórico importante para a compreensão da situação do adolescente em conflito com a lei. Para ele, a normalidade é uma construção social mantenedora de uma ordem estável, construída pelas interações sociais reiteradas e reconhecidas como familiares. Nessa linha de raciocínio, a construção de atributos que categorizam as pessoas, de tão reiterados, acaba por torná-los comuns e naturais.

Essas categorias, por sua vez, permitem classificar pessoas desconhecidas sem que haja um processo de julgamento mais profundo. A associação dos atributos pré-constituídos, quando visíveis e verificáveis em alguém, serve de referência para orientar as interações pessoais. Essa ferramenta de interação é denominada pelo autor de identidade social, na qual as pessoas se apoiam inconscientemente, aplicando-a ao "outro". A identidade social virtual é, ao mesmo tempo, um construto forjado socialmente e os atributos que de fato o indivíduo possui, que são seus valores adiscritivos constitutivos de sua identidade social real. O que ocorre com o estigmatizado é que ele não apresenta os atributos da norma familiar e, por isso, por ser "diferente", é classificado de maneira excludente: "Deixamos de considerá-lo criatura comum e total, reduzindo-o a uma pessoa estragada e diminuída” (GOFFMAN, 1988, p. 14). A atitude do chamado normal, "nós e os que não se afastam negativamente das expectativas particulares”, é considerada pelo autor como resposta discriminatória (GOFFMAN, 1988, p. 14).

Construímos uma teoria do estigma, uma ideologia para explicar a sua inferioridade e dar conta do perigo que ela representa, racionalizando algumas vezes uma animosidade baseada em outras diferenças, tais como as de classe social. Utilizamos termos específicos de estigma como aleijado, bastardo, retardado. (GOFFMAN, 1988, p. 15) 
O adolescente em conflito com a lei possui uma identidade social marcada pelo desvio, seja pelo conhecimento de sua trajetória, seja por seus atributos pessoais, como a forma de vestir, andar e falar, que identificam sua origem social e que são usualmente associados a uma série de estereótipos ligados à marginalidade.

O autor define estigma como uma relação entre atributos e estereótipos que, se assumida pelo estigmatizado como condição já conhecida, o tornam desacreditado, e, nos casos em que essa condição não é conhecida pelos presentes nem imediatamente perceptível, estaremos diante do desacreditável. À medida que o estigma corresponde a um afastamento dos padrões convencionados como socialmente legitimados, as relações entre os normais e os estigmatizados encontram-se ameaçadas.

A seletividade e o estigma no tratamento conferido ao adolescente pela polícia são aspectos importantes para a compreensão da atuação do Estado em relação ao adolescente em conflito com a lei. Isso evidencia o incremento do ciclo de violência perpetrada pela desigualdade social, que está presente desde o início e ao longo de toda a persecução infracional. Essa situação representa o maior entrave para o êxito da defesa do estigmatizado no processo de apuração de ato infracional.

O defensor, diante desse quadro, encontra-se em situação de grande desvantagem em comparação com seu opositor, o promotor de Justiça, que, aprioristicamente, possui legitimidade de suas ações, que se encontram imantadas pela concepção punitivista em vigor no momento histórico em que vivemos. Nessa perspectiva, a noção de campo jurídico de Bourdieu (1989) é adequada para entender como as relações de poder distribuídas de maneira assimétrica entre os agentes no subcampo do direito da criança e do adolescente interferem significativamente no exercício do contraditório e da ampla defesa.

\section{A PRODUÇÃo DE PROVAS E SEUS REFLEXOS NO JULGAMENTO DE ATOS INFRACIONAIS}

Para entender a atuação do Estado no sistema de segurança e de justiça juvenil, analisamos como é realizada a gestão de provas ao longo da persecução infracional e seus reflexos no exercício do contraditório e da ampla defesa.

Verificamos nos processos pesquisados que os elementos probatórios, produzidos na fase inquisitiva da persecução infracional, serviram como principal fundamento das decisões judiciais. Foi constatado que em $84,4 \%$ dos casos a defesa técnica não produziu qualquer prova para confrontar a acusação, conforme se verifica na Tabela 3, a seguir. 
TABela 3 - Processo de APURAÇÃo de ATO INFRACIONAL POR PROVAS PROdUZIDAS PELA DEFESA

PROVAS PRODUZIDAS PELA DEFESA

CASOS

CASOS (\%)

\begin{tabular}{lcc}
\hline NÃO PRODUZIU PROVAS & 76 & 84,4 \\
\hline TESTEMUNHA DAS CIRCUNSTÂNCIAS DO ADOLESCENTE & 7 & 7,8 \\
\hline PERÍCIA MÉDICA & 1 & 1,1 \\
\hline MATRÍCULA DA ESCOLA & 1 & 1,1 \\
\hline NÃO HOUVE AUDIÊNCIA/JOVEM NÃO LOCALIZADO & 5 & 5,6 \\
\hline TOTAL & 90 & 100
\end{tabular}

Fonte: Elaboração própria, a partir de dados produzidos dos processos de conhecimento, consultados no JIJ Goiânia/GO.

Esse resultado indica que apenas $10 \%$ dos adolescentes conseguiram produzir provas na fase judicial. De outro lado, corroborando essa análise, a Tabela 4 apresenta um percentual relevante de que as provas produzidas em fase inquisitiva servem ao juiz como fundamento para sua decisão, confirmando seu valor probatório.

TABela 4 - Processo de APURAÇÃo do ATO INFrACIONAL POR CORRELAÇÃo ENTRE DECISÃO DE PRIMEIRO GRAU E INQUÉRITO POLICIAL

\begin{tabular}{|c|c|c|c|c|}
\hline & & $\begin{array}{l}\text { SE H } \\
\text { DE IN }\end{array}$ & $\begin{array}{l}\text { TAURA } \\
\text { POLIC }\end{array}$ & \\
\hline & & SIM & NÃO & TOTAL \\
\hline DECISÃO & INTERNAÇÃO & 37 & 0 & 37 \\
\hline PRIMEIRO GRAU & LIBERDADE ASSISTIDA & 3 & 0 & 3 \\
\hline & PRESTAÇÃO DE SERVIÇO À COMUNIDADE & 1 & 0 & 1 \\
\hline
\end{tabular}

(continua) 


\begin{tabular}{|c|c|c|c|}
\hline & \multicolumn{2}{|c|}{$\begin{array}{l}\text { SE HOUVE INSTAURAÇÃO } \\
\text { DE INQUÉRITO POLICIAL }\end{array}$} & \multirow[b]{2}{*}{ TOTAL } \\
\hline & SIM & NÃO & \\
\hline MAIORIDADE PENAL & 13 & 0 & 13 \\
\hline IMPROCEDENTE POR FALTA DE PROVAS & 3 & 4 & 7 \\
\hline REMISSÃO & 9 & 0 & 9 \\
\hline LIBERDADE ASSISTIDA E PRESTAÇÃO DE SERVIC̣O À COMUNIDADE & 20 & 0 & 20 \\
\hline
\end{tabular}

Fonte: Elaboração própria, a partir de dados produzidos dos processos de conhecimento, consultados no JIJ Goiânia/GO.

O interrogatório do(a) adolescente realizado na delegacia e na audiência informal, as oitivas da(s) vítima(s) e da(s) testemunha(s) do fato e do(s) policial(is) que apreendeu(ram) o(a) adolescente, realizadas na delegacia, e as perícias realizadas pela polícia científica são anteriores à existência de processo judicial, ou seja, sem a participação de advogado(a) de defesa.

Ademais do exposto, é importante registrar que, nas audiências de continuação, destinadas à produção de provas na fase judicial, a Defensoria Pública não realizou uma defesa apropriada, em função das próprias dinâmicas relacionadas à rotina estabelecida para o ambiente forense. Um exemplo dessa situação é o fato de os defensores acessarem os autos praticamente no horário das audiências. Portanto, os atos probatórios produzidos em audiência de continuação resumem-se, na maioria das vezes, na confirmação do valor dos elementos probatórios produzidos em fase inquisitorial, não havendo, assim, verdadeiro contraditório na fase judicial.

Em tese, o exercício do contraditório é utilizado como método de investigação da verdade, e a gestão das provas está a cargo das partes. O juiz deve permanecer em uma posição passiva e distante da busca por provas. O processo, nessa perspectiva, desenvolve-se pela disputa entre a acusação e a defesa, em igualdade de condições, para informar o juiz quanto aos fatos. Nesse modelo, há a concepção de uma verdade controlada, obtida por meio das controvérsias entre as partes, em que se estabelece uma situação de oposição em igualdade de direitos, deveres, faculdades e ônus. Assim, as garantias processuais devem ser consideradas em função da liberdade dos inocentes diante do arbítrio do Estado.

A análise da gestão de provas do sistema de segurança e de justiça juvenil em Goiânia aponta que, na prática, dá-se ênfase aos elementos probatórios produzidos na fase inquisitiva 
da persecução infracional, não conferindo ao adolescente a oportunidade de exercer efetivamente seu direito ao contraditório e à ampla defesa.

\section{I. OS ELEMENTOS PROBATÓRIOS PRODUZIDOS NA FASE INQUISITIVA DA PERSECUÇÃO INFRACIONAL}

$\mathrm{Na}$ análise dos processos de julgamentos de adolescentes em conflito com a lei em Goiânia, foi possível encontrar elementos que ajudam a captar diversos aspectos da fase inquisitorial ao longo da persecução infracional. Podemos citar, como exemplo, o caso do deferimento de internação provisória pelo juiz somente com base nos documentos que acompanham a petição inicial de representação do MP, como: relatório do inquérito policial; parecer técnico de psicólogos; oitiva com o MP; registro de passagens pela delegacia; extrato da Justiça de processos findos e em andamento contra o adolescente.

Encontramos nos processos de ato infracional uma quantidade expressiva de representações fundadas, principalmente, em inquéritos policiais, demonstrando a necessidade de compreender os reflexos da atuação da polícia no exercício do direito ao contraditório e à ampla defesa. Dos processos analisados, a maior parte resultou em decisão de internação, como se pode ver na Tabela 5, e, destes, 88,9\% iniciaram-se por meio da apreensão do adolescente em ação de ronda da Polícia Militar.

Após a apreensão do adolescente pela Polícia Militar, dá-se início à apuração do ato infracional. Em Goiás, a Delegacia de Apuração de Atos Infracionais (Depai) é a responsável por isso, e é o local destinado à manutenção de adolescentes apreendidos em flagrante de ato infracional e de instauração do inquérito policial.

TABela 5 - Processo de APURAÇÃo de ATO INFraCiOnAl POR INTERNAÇÃo MEdiANTE AÇÃO POLICIAL

FREQUÊNCIA PERCENTUAL PERCENTUAL VÁLIDO

\begin{tabular}{lccc}
\hline SIM & 80 & 88,9 & 88,9 \\
\hline NÃO & 10 & 11,1 & 11,1 \\
\hline TOTAL & 90 & 100,0 & 100,0
\end{tabular}

Fonte: Elaboração própria, a partir de dados produzidos dos processos de conhecimento, consultados no JIJ Goiânia/GO.

Na Depai de Goiânia funciona o programa de atendimento Plantão Interinstitucional (PI), e, pelo artigo 88, inciso V, da Lei n. 8.069/1990 e pelo artigo 4, inciso X, da Lei n. 12.594/2012, 
atualmente estão presentes nesse local representantes do Ministério Público, da Segurança Pública e da Assistência Social. É importante destacar que nem a Defensoria Pública nem o Poder Judiciário têm representação nesse local, o que pode implicar prejuízo à defesa dos(as) adolescentes e repercutir desfavoravelmente em seus julgamentos, uma vez que esse é o momento em que se reúnem elementos probatórios relacionados à autoria e à materialidade do suposto ato infracional, os quais constarão no relatório do inquérito e, posteriormente, servirão de subsídio ao MP tanto na oitiva informal quanto na representação, se oferecida. Ou seja, interroga-se o adolescente, escutam-se os(as) policiais militares condutores(as) do(a) adolescente, a(s) vítima(s) e a(s) testemunha(s) do ato infracional, se houver, apreendem-se materiais em posse do(a) adolescente conduzido(a), entre outros procedimentos que forem entendidos como necessários, tudo isso sem a obrigatoriedade da presença de um(a) defensor(a). Ou seja, no momento em que se inaugura a persecução infracional, os agentes responsáveis pela acusação posicionam-se em grande vantagem diante da ausência de representantes da Defesa do(a) adolescente perante o Poder Judiciário.

Outro aspecto relevante foram os conteúdos dos pareceres emitidos pelos assistentes sociais que atendem na Depai. A abordagem ao adolescente, quando este chega conduzido pela Polícia Militar, está pautada em aspectos emocionais e sociais que se sobrepõem às questões relacionadas ao ato infracional. As informações registradas pelos técnicos refletem posicionamentos pessoais, na maioria das vezes, depreciativos. Assim como consta no trecho de um relatório técnico:

Nome, idade, primeira passagem pela Depai. Assume ato de Tentativa de Roubo Qualificado. Afirma que prática dos atos delitivos são decorrentes de ambição (ter celular, moto), "quer crescer rápido e acaba não saindo do lugar” [...]. Nega o uso de drogas. Reside com mãe. Afirma arrependimento e que deseja arranjar outro emprego (?), aparentemente uma tentativa de sensibilizar.

E, quando o adolescente apresenta uma informação positiva sob sua personalidade, essa informação é seguida de ponto de interrogação, como se fosse duvidosa a versão contada por ele. Em outra situação, o parecer elaborado por um assistente social exibe diagnóstico próprio de um especialista em psiquiatria.

Seu discurso não evidencia arrependimento ou sentimento em relação às vítimas. Em relação à família disse que possui bom relacionamento com a mãe, porém sua fala demonstrou[,] e ele também assumiu[,] que às vezes não acata as orientações recebidas. Verbalizou que a mãe passa por tratamento contra câncer na garganta. Mas pareceu que o enfrentamento da mãe a uma grave doença não o comove, pois não expressou alteração da emotividade durante o relato. Sua postura foi tranquila e [havia] certo ar de superioridade durante a entrevista. 
Esses relatórios psicossociais, que acompanham o flagrante, têm servido como prova para a decisão do juiz quanto à decretação ou não da internação. No caso a seguir, o MP requereu a decretação da internação provisória com fundamento no parecer técnico e nos demais documentos do inquérito policial.

Nome, idade, segunda passagem pela Depai. Nega o ato de Tentativa de Homicídio. Relata que estava no Setor Garavelo num carro com mais quatro maiores. Afirma que estavam indo para festa no Setor Itaipu (festa de Jonhy). E que[,] ao serem abordados pela polícia[,] empreendeu fuga, pois no carro havia uma arma (revólver 36). Afirma que a polícia atirou, tendo inclusive acertado a orelha de um dos passageiros. Por outro lado, nega que tenha efetuado disparos contra os policiais. O adolescente informa que cursou até [o] $3^{\circ}$ ano do Ensino Fundamental. Que trabalha como ajudante de servente. Nega o uso de drogas. Informa que mora com os avós, que não vê a mãe há 10 anos e que tem contato com o pai. (Destaque do original)

Ainda na fase inquisitiva da persecução, após a apreensão do adolescente e seu atendimento na delegacia de polícia, ele será encaminhado ao MP/GO instalado na JIJ de Goiânia, Centro de Apoio Operacional (CAO). Nesse primeiro contato, em oitiva informal com esse adolescente, suposto autor de ato infracional, o juiz poderá, com base em seu convencimento, decidir por medidas protetivas ou socioeducativas sem a presença obrigatória de defensores públicos ou advogados particulares. ${ }^{\mathbf{2 4}}$

Estudos realizados por Santos (2016) confirmam que, nas oitivas informais em Goiânia, prevalece a adoção de medidas socioeducativas em detrimento de medidas protetivas. Das 12 audiências assistidas pela pesquisadora, em nenhuma delas houve aplicação de medidas protetivas, mesmo em ocasiões que demandavam assistência psicológica, situação em que a presença de um advogado ou da Defensoria Pública poderia ter garantido a aplicação de uma medida protetiva em lugar da socioeducativa.

A ausência da defesa não impede o MP de requerer internação provisória do adolescente inquirido nessa etapa da persecução, nem mesmo que se aplique a remissão, já mencionada, cumulada com medida socioeducativa. Nota-se que, de posse do inquérito policial, o MP, em muitos casos, obtém a confissão do adolescente, já realizada anteriormente perante o delegado de polícia. O argumento utilizado, nessas situações, é que se trata de atos de investigação de natureza inquisitiva e que, por lei, não há obrigatoriedade da presença da defesa visando à formação do convencimento ministerial. Um estudo sobre as medidas socioeducativas de

24 A não obrigatoriedade da presença da defesa técnica por advogado revela um aspecto problemático da persecução infracional, uma vez que a omissão do legislador representa uma ofensa ao direito ao contraditório dos adolescentes acusados de prática de ato infracional. 
Goiânia, produzido a partir de consultas a prontuários disponibilizados pela Secretaria Municipal de Assistência Social, informa que, em um total de 287 audiências, apenas em dois casos constatou-se a presença da defesa (MARTINS, 2016).

O art. 179 do ECA prevê que haja oitiva informal do adolescente, entretanto, o dispositivo legal é omisso em relação à necessidade da presença da defesa técnica nesse procedimento. Questionam-se a legalidade e a constitucionalidade de tal omissão, especialmente porque ofende o princípio do contraditório e da ampla defesa.

Projetos de lei têm sido apresentados ${ }^{\mathbf{2 5}}$ visando solucionar tal problemática, propondo a alteração do art. 179 do ECA, com vistas a garantir ao adolescente acusado de ato infracional o direito à defesa no momento da oitiva informal junto ao MP, mediante a presença de advogado constituído ou defensor público nomeado em juízo.

Ocorre que a ausência de defensor em todas as etapas da persecução infracional ofende também princípios previstos no próprio ECA. O art. 111 elenca as garantias asseguradas ao adolescente no curso do processamento do ato infracional, entre elas, o direito à paridade de armas e à defesa técnica. O art. 141 assegura à criança e ao adolescente o acesso à Defensoria Pública, mostrando-se necessária a presença de um defensor em todo o procedimento de apuração do ato infracional. O artigo 206, caput e parágrafo único, também do ECA, deixa claro que não é legítimo o procedimento de “oitiva informal” sem a presença da defesa técnica do adolescente em todas as fases procedimentais, sejam elas judiciais, sejam administrativas.

Art. 206. A criança ou o adolescente, seus pais ou responsável, e qualquer pessoa que tenha legítimo interesse na solução da lide poderão intervir nos procedimentos de que trata esta Lei, através de advogado, o qual será intimado para todos os atos, pessoalmente ou por publicação oficial, respeitado o segredo de justiça.

Parágrafo único. Será prestada assistência judiciária integral e gratuita àqueles que dela necessitarem.

Dados da pesquisa de campo em Goiânia informam que a maioria dos processos analisados $(95,6 \%)$ resultou da apreensão do adolescente pela ação da Polícia Militar e da posterior abertura de inquérito pela Depai, e que os resultados dos inquéritos subsidiaram a atuação tanto do MP, quando da oitiva informal, assim como dos demais agentes na fase judicial da persecução, influenciando mais tarde a decisão judicial, como mencionado. do Congresso Nacional, com a apresentação do Projeto de Lei n. 259/1999. Contudo, após aprovação pelo Legislativo, houve veto presidencial no ano de 2000. Projeto de Lei n. 5.876, de 2013, de autoria da deputada Luiza Erundina. 


\subsection{JUDICIALIZAÇÃO DOS ELEMENTOS PROBATÓRIOS NA PERSECUÇÃO INFRACIONAL}

O MP, após a oitiva informal, terá que escolher entre três caminhos: a) promover o arquivamento do caso; b) conceder remissão com ou sem medidas socioeducativas em meio aberto; ou c) representar em face do adolescente ao juiz.

No primeiro e no segundo caminhos, o promotor deve homologar a decisão junto ao juiz. Este, não concordando com o promotor, remete os autos ao procurador-geral de Justiça, que oferecerá a representação e designará outro promotor para o caso.

No terceiro caminho, oferece-se a representação combinada com pedido de internação provisória ou não. A internação provisória equipara-se à prisão preventiva prevista no Código de Processo Penal (CPP). Seu requerimento é feito em peça separada da petição de representação, e em tudo se assemelha a uma denúncia. Utiliza-se da linguagem criminal e da tipificação conforme o CPP. A medida cautelar não pode exceder 45 dias, tempo máximo para a apuração de ato infracional (arts. 108 e 183 do ECA) e para que o julgamento seja concluído.

O que se notou a respeito do tempo para a apuração dos atos infracionais, com aplicação de internação provisória, é que não houve nenhum caso de excesso de prazo. Contudo, na maioria deles, os adolescentes ficaram pelo menos 30 dias internados aguardando a conclusão do processo, o que pode ser considerado como antecipação de pena. Segundo o que foi relatado pelos defensores, é de praxe chamar a internação provisória de internação "susto". Um dos defensores arguidos sobre a internação provisória respondeu:

É dito abertamente por um promotor de justiça no sentido de que a internação provisória é medida efetiva, uma forma de se dar um susto no adolescente. Então, se essa é a visão do membro do Ministério Público que pede a internação provisória e também é a visão de alguns juízes, está havendo cumprimento de pena sem formação de culpa, sem produção de provas e sem garantia da ampla defesa e do contraditório.

Dos 90 casos em que houve a aplicação da internação provisória, 58,88\% não tiveram internação confirmada em decisão final, o que demonstra que esses adolescentes sofreram restrição de liberdade desnecessariamente ou que a internação provisória, por si, representou uma antecipação de pena.

Após o deferimento ou não do pedido de internação provisória, o próximo ato é a audiência de apresentação. Nela é que se encontram os principais envolvidos na segunda fase da persecução infracional (acusação, juiz, defesa e acusado). A atuação desses sujeitos é marcada por um procedimento-padrão, definido por uma formalidade burocrática em que é possível identificar, na postura de cada um, a marca da instituição que representa. A disposição do mobiliário da sala de audiência reforça a ideia de hierarquia nas relações claramente materializadas ali. O juiz fica no centro de uma mesa, disposta na horizontal, paralela a uma parede onde foi afixado um quadro enorme com a figura de Jesus Cristo. Em cada lado da mesa se posicionam o promotor e o defensor. O adolescente é colocado em frente ao juiz. 
A impressão que fica é a de que Cristo transmite a ideia da iluminação divina na atuação do juiz e um olhar misericordioso à situação do adolescente ali julgado. Na sala permanece também um policial militar.

É nesse momento que ocorre o primeiro contato visual entre o juiz e o acusado. É também o primeiro contato do adolescente com a Defensoria Pública. Então, o juiz poderá conceder a remissão (suspensiva ou extintiva do processo, com ou sem medidas) ou revogar, manter ou decretar a internação provisória.

Nesse tipo de audiência, foi observado que a atuação do juiz é dirigida para a obtenção da confissão do adolescente. O número de confissões nos processos judiciais é representativo, assim como a relação delas com a decisão final do processo, de acordo com a Tabela 6.

TABela 6 - Processo de APURAÇÃo de ATO INFrACIONAl POR CORRELAÇÃo ENTRE DECISÃO JUDICIAL EM PRIMEIRO GRAU E CONFISSÃO

\begin{tabular}{|c|c|c|c|c|c|}
\hline \multirow[b]{2}{*}{ DECISÃO } & \multirow[b]{2}{*}{ CASOS } & \multirow[b]{2}{*}{ CASOS $(\%)$} & \multicolumn{3}{|c|}{$\begin{array}{l}\text { CONFISSÃO } \\
\text { PERANTE O JUIZ }\end{array}$} \\
\hline & & & SIM & NÃO & AUSENTE \\
\hline INTERNAÇÃO & 37 & 41,1 & 26 & 11 & 0 \\
\hline LIBERDADE ASSISTIDA & 3 & 3,3 & 2 & 1 & 0 \\
\hline PRESTAÇÃO DE SERVIC̣OS À COMUNIDADE (PSC) & 1 & 1,1 & 1 & 0 & 0 \\
\hline MAIORIDADE PENAL & 13 & 14,4 & 7 & 1 & 5 \\
\hline FALTA DE PROVAS & 7 & 7,8 & 0 & 7 & 0 \\
\hline REMISSÃO COM MEDIDAS EM MEIO ABERTO & 9 & 10 & 8 & 1 & 0 \\
\hline LIBERDADE ASSISTIDA E PSC & 20 & 22,2 & 15 & 5 & 0 \\
\hline
\end{tabular}

Fonte: Elaboração própria, a partir de dados produzidos dos processos de conhecimento, consultados no JIJ Goiânia/GO. 
A obtenção da confissão por parte da autoridade judicial alcança um percentual de 71,1\%, considerado alto. No modelo processual garantista, o interrogatório deveria ser o principal meio de defesa, sendo vedado qualquer método que viole o direito ao silêncio. A presunção da inocência deveria ser um dos princípios a serem observados nesse momento. No entanto, o que foi possível perceber é que, na prática da apuração do ato infracional, há grande expectativa na obtenção da confissão, seja para uma avaliação moral favorável ao adolescente - o que, em tese, deveria contribuir para amenizar a situação processual do acusado -, seja para fundamentar a sentença condenatória. Por outro lado, a não confissão incide de maneira importante no desfecho do processo, como informado, ainda, pelos dados da Tabela 6. Dos 26 casos em que não houve confissão, sete foram arquivados por falta de provas.

Outra problemática já mencionada é a falta de contato prévio à audiência de apresentação entre o defensor público e o adolescente. A ausência de uma estratégia de defesa prejudica a produção de provas favoráveis. Nas audiências de apresentação assistidas, os defensores tomaram conhecimento das particularidades do caso no ato da audiência. Basicamente, as perguntas da Defensoria abordaram aspectos associados às relações com a família, com a escola e com o trabalho. Também houve questionamento sobre o arrependimento pela prática do ato infracional; sobre a ciência do certo e do errado; e se há um projeto de vida. O que se pode extrair disso é que a Defensoria, impossibilitada de oferecer o contraditório, cuida de acompanhar, dali para a frente, a trajetória do acusado, direcionando a defesa para a aplicação de medidas protetivas e socioeducativas em meio aberto.

Quanto ao duplo grau recursal - direito relacionado à ampla defesa - dos processos analisados, em nenhum houve recurso endereçado aos tribunais de segunda instância, tampouco aos de terceira instância. Nem mesmo foi encontrado pedido de habeas corpus (HC) em favor do adolescente internado provisoriamente. Questionados em entrevista, os defensores justificaram esse fato, afirmando que, muitas vezes, as petições de HC interpostas pela Defensoria não eram juntadas nos autos processuais. E que, além disso, as dificuldades materiais e de pessoal da Defensoria para recorrer, os frequentes indeferimentos sem fundamentos jurídicos pelo tribunal e, ainda, a celeridade do julgamento do ato infracional acarretam em perda do objeto, tornando o HC medida inócua.

Nas entrevistas, os defensores registraram que, apesar desses obstáculos, recorrem ao tribunal do Estado sempre que veem a possibilidade de modificar a decisão e que, nos últimos tempos, vêm realizando a sustentação oral dos recursos interpostos, o que já garantiu algumas decisões favoráveis, inclusive em recurso interposto perante o Superior Tribunal de Justiça (STJ). Contudo, segundo eles, seriam necessários mais recursos materiais e de pessoal para que a Defensoria efetivamente pudesse exercer o duplo grau jurisdicional.

$\mathrm{Na}$ audiência de apresentação, não havendo decisão de remissão suspensiva ou extintiva do processo, o próximo ato processual é a audiência de continuação, a qual deve ocorrer dentro do prazo máximo de 45 dias. Entre a audiência de apresentação e a de continuação, diligências podem ser promovidas no sentido de produzir provas, podendo ser determinadas pelo 
juiz e requeridas pelas partes. Quanto a esse aspecto, a pesquisa demonstrou a desproporção existente entre provas produzidas pela defesa em comparação com as produzidas pela acusação, as quais, muitas vezes, eram as mesmas utilizadas na fase inquisitorial, como já demonstrado. Após a (re)produção de provas em audiência, passa-se às alegações finais orais proferidas pelo MP e pela defesa. Nessa etapa, foi possível perceber a desatenção do juiz em relação à fala do defensor público. Houve situações em que, tão logo o MP apresentava suas alegações finais, o juiz saía da sala no momento em que a Defensoria iria registrar oralmente seus argumentos quanto ao caso em julgamento. Isso aconteceu em diversas audiências assistidas. Questionados, os defensores disseram que esse tipo de situação se repetia com frequência, conforme a fala de um deles:

Uma prática odiosa de alguns juízes e alguns promotores. Um total desrespeito ao adolescente que está tendo seu futuro decidido ali, e é um desrespeito também à defesa e à Defensoria Pública. Em alguns casos, alguns defensores chegam a interromper a fala, outros solicitam a presença de juiz, mas, como nós temos essa relação diária junto aos juízes, ao mesmo tempo em que nós devemos fazer essa defesa intransigente, nós temos essa dificuldade no relacionamento entre as instituições. Houve até uma situação que aconteceu comigo, em que um juiz, o dr. X, saiu da sala de audiência e passou os autos ao promotor, para que ele fizesse a inquirição da testemunha. Pelo que está previsto no art. 212 do CPP, é certo que o juiz passe as perguntas ao promotor, depois para [a] defesa, e só depois se tiver alguma pergunta complementar é que ele faz. Mas o que este juiz fez, na verdade, foi passar a presidência da audiência para o promotor.

Esse tipo de situação reafirma o caráter inquisitivo do sistema de segurança e de justiça juvenil, confirmando a hipótese levantada neste trabalho de que os adolescentes acusados de ato infracional não têm garantidos o exercício do contraditório e o direito à ampla defesa.

Após as alegações finais, passe-se à decisão do juiz, que ocorre no momento final da audiência de continuação. Caso não seja aplicada a remissão extintiva do processo, o juiz poderá decidir pela absolvição ou condenação do adolescente, com a respectiva medida socioeducativa.

De maneira geral, a decisão é seguida de um "sermão" ou "aconselhamento", com apontamentos sobre o "mau" comportamento do acusado, alertando-o sobre a importância do bom desempenho na escola, em casa e no trabalho. O juiz profere algumas palavras que ilustram bem essa observação. Entre elas: "Tem que querer menos. Esse é o segredo da felicidade”; “Tem que andar certo para não sofrer"; "Você pode querer jatinho, carro, mas tem que trabalhar para conseguir"; "Olha, não quero ver você no Natal do ano que vem”; "Não jogue seu futuro na lata do lixo"; "Cace um jeito de trabalhar e de estudar"; "Você tem casa, cama, comida, sua mãe se sacrificando"; "No Brasil de milhões de desempregados, conseguir trabalho sendo fichado é difícil. O preconceito é grande”; "Não dê mais bobeira”; “Aquilo ali não é vida de gente”; "Depende de você evitar isso". 
Esse discurso evidencia o entendimento de que os atos infracionais ocorriam em decorrência de características pessoais negativas, presumindo que os adolescentes são preguiçosos e ambiciosos. Nessa perspectiva, o Estado aplica medidas socioeducativas, institucionalizando adolescentes, não só para responsabilizá-los pelo ato infracional praticado, mas também como forma de controlá-los, como indivíduos que estão em condições de vulnerabilidade social e econômica, a partir de julgamentos morais assentados em valores das camadas dominantes da sociedade.

O Judiciário tem como função primordial a solução dos conflitos, de modo a observar o devido processo legal, competindo ao juiz analisar os argumentos e os documentos apresentados pela acusação (MP-Estado) e pela defesa (Defensoria Pública-adolescente), além de presidir as audiências de apresentação e continuação e, ao final, decidir se a acusação é procedente ou improcedente com base na lei e nas provas produzidas. Dentro da dinâmica de julgamento, o juiz deve se ater à análise de cada um dos casos, guiado pelos limites impostos por leis processuais (civil e criminal) do ECA, do Sinase e da CRFB/88.

Atualmente, o paradigma da proteção integral obriga os juízes a observarem o devido processo legal e a fundamentarem suas decisões a partir da interpretação sistemática das leis, aplicando-as ao caso concreto. Contudo, na análise da atuação dos juízes do JIJ de Goiânia/ $\mathrm{GO}$, pode-se perceber que os limites introduzidos pelo novo conjunto de normas, por vezes, foram suplantados pela visão fundada pelo paradigma da situação irregular dos adolescentes com ato infracional. Um dos exemplos foi a tomada de decisão da direção do juizado, exercida sem a consulta prévia à Defensoria, de retirá-la do prédio do juizado para colocar, em seu lugar, um atendimento assistencial, denominado Programa Pai Presente. É interessante notar que, na justificativa do programa, constam parcerias com diversas instituições públicas, menos com a Defensoria Pública.

A atuação assistencialista por parte dos representantes do Judiciário repercute a permanência da atuação paternalista da figura do juiz, aquele que aplica medidas socioeducativas com a finalidade de recuperar e minimizar a "vulnerabilidade" a que estão expostos os adolescentes. Ainda é comum familiares procurarem os juízes para pedir ajuda para seus(suas) filhos(as).

Outro aspecto que evidencia a permanência do paradigma da situação irregular é o das justificativas para a internação, ancoradas na situação social do(a) adolescente. A seguir, há um trecho redigido em negrito pelo MP em um dos processos analisados:

A adolescente é órfã de mãe e o pai vive em Curitiba/PR, o qual presta auxílio em dinheiro e acompanha a filha por contatos telefônicos. A adolescente vive com um irmão de 21 anos, cunhada e sobrinho, sendo sua avó sua responsável. [...] Por tudo que foi exposto acima, percebe-se que a adolescente se encontra em extrema vulnerabilidade social e, apesar de morar com familiares, não possui referenciais sólidos de conduta, tão essenciais para o desenvolvimento, visto que a mãe faleceu há pouco tempo (um ano), o pai vive distante, ela não quer morar com a avó, apesar de ser sua responsável, e vive com um 
irmão também muito jovem. A internação se mostra, neste caso, uma medida extremamente necessária para sua proteção, uma vez que nenhum familiar pode acompanhá-la durante os procedimentos na delegacia e na oitiva informal; liberá-la agora significaria devolvê-la aos criminosos que a aliciaram a cometer um ato infracional tão grave.

Nesse mesmo caso, a Defensoria requereu a desinternação; contudo, o Tribunal de Justiça de Goiás concluiu que: "Logo, tem-se que segregação provisória da adolescente é medida imperiosa que se impõe para a preservação da ordem pública e proteção da própria adolescente”.

O paradigma da situação irregular tinha como principal preocupação as condições de "moléstia social" dos "menores infratores". Os maus-tratos, a negligência por parte da família ou da própria sociedade eram fundamentos para a institucionalização. Nesse passo, a judicialização das questões sociais, desde aqueles tempos até os atuais, reforça a discriminação entre “crianças” e "menores”. Segundo Silva,

[...] ter ou não ter cometido infração, ter ou não ter as garantias constitucionais era irrelevante, pois o objetivo central era a prevenção dos “desvios" de crianças, adolescentes e jovens "potencialmente perigosos". O que estava em jogo era um ideal de sociedade a ser construída. (SILVA, 2005, p. 61)

Esse modelo prioriza a institucionalização e a adoção dos "menores" por outras famílias, em detrimento de políticas públicas efetivas no combate às desigualdades sociais. Nesse contexto, a atuação judicial ganha centralidade na figura do juiz, que possui competência ilimitada e discricionária para apresentar solução judicial de questões relacionadas ao empobrecimento de crianças e adolescentes, acarretando, com isso, a criminalização da pobreza (MÉNDEZ, 1996).

Neste ponto, pode-se perceber que, para além de todo o sistema de segurança e de justiça juvenil não estar estruturado de modo a conferir à Defensoria Pública condições materiais e de pessoal necessárias para prestar uma efetiva defesa técnica, a permanência do paradigma da situação irregular orientando, de modo substancial, as ações dos agentes no interior do subcampo do direito da criança e do adolescente em Goiânia prejudica o exercício do contraditório e da ampla defesa, além de outros direitos previstos pelo paradigma da proteção integral.

\section{CONSIDERAÇÕES FINAIS}

No Brasil, o recrudescimento penal é apontado como solução para enfrentar o fenômeno da violência e, nesse sentido, como a alternativa mais viável no tratamento dispensado aos adolescentes em conflito com a lei. Atualmente, discutem-se propostas legislativas de redução da maioridade penal e de aumento do tempo de internação, em que pesem os dados informados 
pelo Levantamento Anual do Sinase 2014, publicado em 2017 pelo Ministério dos Direitos Humanos vinculado à Secretaria Nacional dos Direitos Humanos da Criança e do Adolescente (BRASIL, 2017) sobre, por um lado, a diminuição de atos infracionais praticados entre 2010 e 2014 e, por outro, o aumento do índice de adolescentes internados confirmados.

Em porcentagem, o homicídio, em 2010, representou 14,9\% do total de atos infracionais registrados no Brasil e, em 2011, esse valor reduziu para 8,4\%. Em 2012, 2013 e 2014, esse total apresentou pequeno aumento e depois uma estabilidade, com, respectivamente: 9,0\%, 9,2\% e 9,5\%. Em contrapartida, os crimes análogos ao roubo, à tentativa de roubo e ao furto, em 2014, representaram, respectivamente, 44\%, 1,24\% e 3,3\%. Por outro lado, segundo a mesma fonte de dados, houve um aumento de adolescentes privados de liberdade. Em 2008, eram 16.868 adolescentes, e em 2009 foram 16.940, representando um aumento de 0,4\%. Em 2010, ocorreu um aumento de 4,5\%, passando, assim, para 17.703 adolescentes privados de liberdade. Em 2011, o número aumentou para 19.595, período em que houve um aumento significativo de 10,5\%. Em 2012, foram registrados 20.532, um aumento de 4,7\% em relação ao ano anterior. Em 2013, ocorreu o segundo aumento significativo: o número foi para 23.066, um aumento de 12\%. Em 2014, houve um aumento de 6\%, totalizando a quantidade de 24.628 adolescentes privados de liberdade. A série histórica de restrição e privação de liberdade indica um aumento constante e regular desde 2010, com predominância para a aplicação da modalidade de internação (66\%). Destaca-se, ainda, o significativo número de internações provisórias, representando 22\% do total de adolescentes em 2014 (BRASIL, 2017).

A combinação de diferentes técnicas de investigação adotada na realização desta pesquisa permitiu compreender as lutas simbólicas que se desenvolvem quanto à aplicação do direito ao contraditório e à ampla defesa nos conflitos concretos. Foi possível também trazer à superfície o conteúdo dos processos de conhecimento de ato infracional, além de conhecer a prática dos profissionais no embate das audiências. As diversas fases da persecução infracional revelaram um julgamento majoritariamente inquisitivo, marcado por atos de investigação e produção de provas, sem a observância do contraditório e da ampla defesa. Provas essas que, na maioria das vezes, foram utilizadas como fundamento para a decretação de internação provisória ou definitiva.

As ações do sistema de segurança e de justiça juvenil, dirigidas a um público selecionado por suas características adiscritivas e por sua classe social, contribuem para a permanência da construção imaginária de um tipo estereotipado de adolescente propenso a cometer delitos. Goffman (1988) afirma que a construção do estigma é uma ideologia perigosa, uma vez que essa racionalidade está baseada em animosidades, em diferenças, criando termos como "aleijado", "delinquente" e "retardado". Violências como essas deixam marcas indeléveis na história dos adolescentes.

Esta pesquisa também verificou que a discricionariedade presente nas decisões, por vezes, implicou em arbitrariedades, como a que foi encontrada nos processos das internações provisórias decretadas, em que 44,4\% culminaram em aplicação de medidas em meio aberto 
e 7,8\%, em processo extinto por falta de provas. Com esses dados, deve-se considerar que 95,6\% dos casos foram instaurados a partir do inquérito policial, o que indica a seletividade operacionalizada inicialmente pela ação da Polícia Militar. A dinâmica estabelecida no interior do sistema de segurança e de justiça juvenil demonstra os limites para a observação do direito ao contraditório e à ampla defesa em favor dos acusados de ato infracional. A apreensão pela Polícia Militar, a audiência informal com o MP, a decretação da prisão provisória, a ausência de defensor público na fase inquisitiva e na audiência de apresentação, a dificuldade da Defensoria quanto à produção de provas em favor do adolescente, a celeridade do processo, a permanência do paradigma da situação irregular e a ausência de recurso das decisões perante os tribunais superiores foram elementos encontrados nesta pesquisa.

Para além dos agentes do sistema de justiça juvenil, percebeu-se, ainda, a atuação significativa de órgãos do sistema de segurança, que compartilham o poder de influenciar o resultado da persecução infracional, como as Polícias Militar e Civil e os técnicos do sistema de atendimento socioeducativo. Soma-se a esse contexto a pressão exercida pela opinião pública, veiculada pela mídia, demandando o endurecimento das penas.

Considerando a perspectiva de Bourdieu (1989) sobre o campo jurídico constituir-se um espaço marcado por uma distribuição desigual do capital jurídico adquirido pelos agentes ao longo de suas trajetórias, percebeu-se uma nítida hierarquia entre os agentes do subcampo do direito da criança e do adolescente em Goiás. O MP tem uma posição mais vantajosa em relação àquela ocupada pela defesa, porque conta com uma estrutura de capital simbólico maior que o da Defensoria, recentemente implementada no estado. O trabalho de campo evidenciou que a atuação do MP baseia-se muito mais em uma concepção punitiva do que de custos legis, em uma sociedade em que o Estado prioriza investimentos em políticas criminais cada vez mais repressivas, em detrimento de políticas sociais que respondam às demandas das populações mais pobres do país.

A não obrigatoriedade de advogado ou defensor público nos procedimentos inquisitivos, a escassa possibilidade de atuação da defesa quanto a influenciar as decisões do juiz, em sua maioria orientada pelo paradigma da situação irregular, e um processo judicial marcado pela celeridade são fatores, entre outros, que também contribuem para que esses adolescentes não tenham acesso a uma defesa satisfatória.

Dessa feita, independentemente da observação dos princípios do contraditório ou da ampla defesa, esse modelo, por si só, não é capaz de superar as contradições presentes na atuação do Estado no interior do subcampo do direito da criança e do adolescente. Este, mesmo diante da presença do advogado e de sua atuação, pune os sujeitos, levando em consideração não o suposto ato infracional atribuído, mas as condições sociais do indivíduo acusado, revelando um sistema inclinado, a priori, a condenar e segregar determinado grupo social.

$\mathrm{Na}$ prática, as instituições que atuam nesse subcampo do direito da criança e do adolescente permanecem reproduzindo os fundamentos do paradigma da situação irregular combinado com a responsabilização penal dos adolescentes. A relação entre proteção e responsabilização 
infracional introduzida pelo ECA tem por base o reconhecimento do adolescente como sujeito de direitos em condição peculiar de desenvolvimento, mas, ao mesmo tempo, sujeito a punição. O que se certifica, na prática, é o predomínio das ações punitivas em detrimento das ações protetivas.

Em uma sociedade marcada pela profunda desigualdade social, em que os bens produzidos socialmente são apropriados de modo desproporcional, o acesso à Justiça também não se encontra, na mesma medida, ao alcance de todos. O sistema de segurança e de justiça juvenil, ao não assegurar o exercício do contraditório e da ampla defesa aos adolescentes que praticam atos infracionais, respalda esse argumento.

\author{
AGRADECIMENTOS \\ Os autores agradecem ao apoio financeiro do Ministério \\ da Ciência, Tecnologia e Inovações e Comunicações, Con- \\ selho Nacional de Desenvolvimento Científico e Tecnológico \\ (CNPq), por meio do Processo n. 132.782/2015-4, conce- \\ dido à autora Lélia Moreira Borges.
}

\title{
REFERÊNCIAS
}

BATISTA, Nilo. Introdução crítica ao direito penal brasileiro. 8. ed. Rio de Janeiro: Revan, 2002.

BOURDIEU, Pierre. O poder simbólico. Rio de Janeiro: Bertrand Brasil,1989.

BRASIL. Código de Menores de 1927. Decreto n. 17.943-A, de 12 de outubro de 1927.

BRASIL. Constituição da República do Brasil. Diário Oficial da União, Brasília, n. 191-A, 5 out. 1988.

BRASIL. Ministério dos Direitos Humanos. 2017. Levantamento anual Sinase 2014. Brasília, 2017.

BRASIL. Presidência da República. 1979. Lei n. 6.697, de 10 de outubro de 1979. Código de menores. Disponível em: http: / /www.planalto.gov.br/ccivil_03/LEIS/1970-1979/L6697.htm. Acesso em: 6 jan. 2020. 
BRASIL. Presidência da República. 1990. Lei n. 9.069, de 13 de julho de 1990. Estatuto da Criança e do Adolescente. Disponível em: http://www.planalto.gov.br/ccivil_03/leis/L8069.htm. Acesso em: 6 jan. 2020.

BRASIL. Presidência da República. 2012. Lei n. 12.594, de 18 de janeiro de 2012. Sistema de Atendimento Socioeducativo. Disponível em: http://www.planalto.gov.br/ccivil_03/_ato2011-2014/2012/lei/ 112594.htm. Acesso em: 6 jan. 2020.

BRASIL. Presidência da República. 1995. Lei n. 9.249, de 26 de dezembro de 1995. Altera a legislação do imposto de renda das pessoas jurídicas, bem como da contribuição social sobre o lucro líquido, e dá outras providências. Disponível em: http://www.planalto.gov.br/ccivil_03/leis/L9249.htm. Acesso em: 6 jan. 2020.

COSTA, Ana Paula Motta. As garantias processuais e o Direito Penal Juvenil: como limite na aplicação da medida socioeducativa de internação. Porto Alegre: Livraria do Advogado, 2005.

GOFFMAN, Erving. Estigma - Notas sobre a manipulação da identidade deteriorada. 4. ed. Rio de Janeiro: LTC, 1988.

LÖWY, Michael. Ideologias e ciência social - Elementos para uma análise marxista. São Paulo: Cortez, 1985.

MARINONI, Luiz Guilherme. Teoria geral do processo. 3. ed. São Paulo: RT, 2008.

MARTINS, Tarihan Chaveiro. O processo e o Estatuto da Criança e do Adolescente: uma análise da apuração do ato infracional à luz da doutrina da proteção integral. 2016. Dissertação (Mestrado em Direitos Humanos) - Universidade Federal de Goiás, Goiânia, 2016.

MÉNDEZ, Emilio García. Infância e cidadania na América Latina. São Paulo: Hucitec, 1996.

MÉNDEZ, Emilio García; BELOFF, Merry (orgs.). Infância, lei e democracia na América Latina. Blumenau: Edifurb, 2001. v. 1.

RIBEIRO, Darcy. O povo brasileiro: a formação e o sentido do Brasil. 2. ed. São Paulo: Companhia das Letras, 1995.

RIZZINI, Irene. O século perdido: raízes históricas das políticas públicas para a infância no Brasil. Rio de Janeiro: Petrobrás-BR: Ministério da Cultura: USU Ed. Universitária, 1997. 
SANTIBANEZ, Dione Antonio de Carvalho de Souza. Sujeição criminal e inclusão marginal no sistema socioeducativo: uma análise qualitativa das percepções de agentes do meio aberto e fechado. 2016. Tese (Doutorado em Sociologia) - Universidade Federal de Goiás, Goiânia, 2016.

SANTOS, Liza Franco Busse Reis dos. Qual é a medida? Um estudo sobre punição e equidade no julgamento da justiça juvenil. 2016. Dissertação (Mestrado em Sociologia) - Universidade Federal de Goiás, Goiânia, 2016.

SILVA, Maria Liduina de Oliveira e. O controle sócio-penal dos adolescentes com processos judiciais em São Paulo. 2005. Tese (Doutorado em Serviço Social) - Pontifícia Universidade Católica de São Paulo, São Paulo, 2005.

WAISELFISZ, Julio Jacobo. Mapa da violência. Brasília: Secretaria-Geral da Presidência da República: Secretaria Nacional de Juventude: Seppir, 2015.

\section{COMO CITAR ESTE ARTIGO:}

BORGES, Lélia Moreira; DURÃES, Telma Ferreira do Nascimento; LOPES, Gustavo de Faria; LIMA, Ricardo Barbosa de. Contraditório e ampla defesa: direitos? 0 que dizem os processos de apuração de ato infracional entre os anos 2014 e 2017 em Goiânia, Goiás. Revista Direito GV, v. 16, n. 1, jan./abr. 2020, e1943. doi: http://dx.doi.org/10.1590/23176172201943.
Lélia Moreira Borges

Pesquisadora do Núcleo de Estudos sobre Criminalidade e ViolênCIA (NECRIVI) dA UnIVERSIDADE FEDERAL DE GoIÁS (UFG). Membro da Comissão dos Direitos da Criança E do Adolescente da OAB/Go. Mestra pelo Programa de Pós-Graduação em Sociologia (PPGS) da UFG. Advogada.

lelia.moreiralahotmail.com

\section{Telma Ferreira do Nascimento Durães}

Docente da Faculdade de Ciências Sociais e do Programa de Pós-Graduação em Sociologia (PPGS) da Universidade Federal de Golás (UFG). Pesquisadora do Núcleo de Estudos SOBRe Criminalidade E VIOLÊNCIA (NeCRIVI) DA UFG.

telmamujer1Agmail.com

\section{Gustavo de Faria Lopes}

Docente do Instituto Federal de Golás (IFG). Doutorando do Programa de Pós-Graduação em Sociologia (PPGS) da Universidade Federal de Goiás (UFG). Pesquisador do Núcleo de Estudos e Pesquisas em Sociologia, Educação e SOCIEDAdE (NEPSES) DO IFG.

gflopes.ifgagmail.com 
CONTRADITÓRIO E AMPLA DEFESA: DIREITOS? O QUE DIZEM OS PROCESSOS DE APURAÇÃO DE ATO INFRACIONAL : $\mathbf{3 4}$

Ricardo Barbosa de Lima

Docente da Faculdade de Ciências Sociais, do Programa de Pós-Graduação em Sociologia (PPGS) e do Programa de Pós-Graduação INTERdisciplinar EM DiReItos Humanos (PPGIDH) DA UNIVERSIDADE FEDERAL DE GoIÁs (UFG). Pesquisador do Núcleo de Estudos sobre Criminalidade e VIOLÊNCIA (NECRIVI) DA UFG.

ricardo.ufglagmail.com 